\title{
O sertão amazônico: o inferno de Alberto Rangel
}

MARGO AURÉLIO GOELHO DE PAIUA"

\section{Resumo}

A partir da análise do livro de estreia de Alberto Rangel, Inferno verde, publicado em 1908, o artigo busca identificar as motivações e os constrangimentos presentes no processo criativo do autor quanto à formulação de uma representação da Amazônia como sertão. A sua filiação ao estilo de Euclides da Cunha e a sua vinculação ao aparato administrativo estatal quando da sua presença na região confluíram para uma ideia de região então assentada em seu aspecto infernista. $\mathrm{O}$ entendimento da realidade nacional a partir dos sertões fez com que a Amazônia fosse tomada pelo autor como um mundo relegado ao esquecimento. Uma interpretação dos diferentes contos do livro e a identificação de uma representação infernista da Amazônia só poderão ser logradas caso leve-se em consideração os aspectos vinculados aos anseios e angústias de Alberto Rangel em tornar-se um escritor e ser reconhecido como tal.

Palavras-chave: Amazônia. Literatura. Região.

* Doutor em Sociologia pela Universidade de São Paulo. Professor Adjunto III do Departamento de Ciências Sociais da Universidade Federal do Amazonas. 
Sociologias, Porto Alegre, ano 13, no 26, jan./abr. 2011, p. 332-362

A bruma é forte, nada se define bem. O frio matinal se dissipa em orvalho morno. Um corpo suado, metálico, mas de um metal escuro, misturando-se por entre formas esverdeadas, vegetais, avança resfolegando como um dinossauro, ou um estegossauro, ou um brontossauro. Há, também, brilhos repentinos de metal cromado, a bruma aumenta em intervalos compassados, é como uma respiração monstruosa, antediluviana, uma respiração num inverno rigoroso, embora o calor seja forte. Os insetos fazem ruído e há uma fricção de metal contra metal. A bruma é escaldante. (Márcio Souza, Mad Maria, 1984, p. 34)

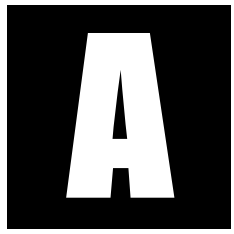

oscilação entre diferentes elementos em tudo antagônicos contidos nessa passagem do romance Mad Maria, de Márcio Souza, acaba por condensar os tons e os ritmos que o processo de modernização ganhou nos ermos amazônicos. A bruma da manhã confunde-se com a fumaça produzida pela locomotiva; a dureza do metal que envolve e molda a máquina em plena selva, com a vegetação espalhando-se em derredor de maneira desordenada, ganha realces de um verdadeiro animal préhistórico; a umidade e o calor da região parecem não só contrastar com o engenho industrial, mas também se convertem em empecilhos quase intransponíveis para o seu deslocamento; os ruídos dos inumeráveis insetos destoam do barulho propiciado pela fricção metálica da máquina que tenta se arrastar em uma superfície sempre úmida. Enfim, um quadro no qual elementos díspares tendem a representar simultaneamente o passado mais distante e o futuro não muito longínquo, mesclando-se uns nos outros para configurar um presente sempre em construção caótica. Essa representação literária da Amazônia consolidou-se ao longo do tempo e invariavelmente é tomada como um lugar-comum. Talvez a própria pai- 
sagem natural da região tenha fortemente contribuído para tal representação, sempre referida em diversos e variados relatos como um mundo ainda em construção.

Mas como a representação de uma dada região não está única e estritamente atrelada aos elementos naturais a compor a sua paisagem, faz-se necessário identificar os atores sociais então engajados na produção dessas imagens que, ao fim e ao cabo, tendem a naturalizar a própria ideia de região (cf. Bourdieu, 1989). Embora seja possível identificar uma tradição no modo da Amazônia ser representada literariamente, e o romance Mad Maria de Márcio Souza é apenas mais um elo de uma corrente que vem se desdobrando ao longo de décadas, a chave explicativa para o entendimento desse processo deve ser buscada na trajetória dos diferentes autores que, ao se debruçarem sobre a temática amazônica, traçaram suas estratégias de filiação a determinadas linhagens literárias em prol de uma provável consagração como escritores, com todos os constrangimentos inerentes ao processo criativo. O livro de contos de Alberto Rangel sobre a Amazônia, Inferno verde, de 1908, converte-se em um caso representativo desse processo.

\section{A Amazônia e a escrita canônica de Euclides da Cunha}

No ensaio "Os intérpretes da Amazônia", publicado em 1935 como o primeiro capítulo do livro Legendas e águas-fortes, o crítico literário amazonense Péricles Moraes intentou fazer um levantamento dos vários autores e obras tidos por ele como os mais relevantes e que mais bem teriam retratado a Amazônia até então. Para isso ele propôs-se a desfiar, entre gigantes e pigmeus (Moraes, 2001, p. 64), autor por autor e obra por obra, com o objetivo de deslindar os distintos princípios que vinham presidindo as diferentes formas de representação literária da região. Deve-se atentar, 
no entanto, para o caráter da crítica literária praticada por Péricles Moraes. Uma crítica de teor ainda impressionista em que se sobreleva o talento de cada autor como fator determinante para o julgamento da obra. Daí talvez a necessidade do crítico de escorar-se em um autor já consagrado e reconhecido para exercer uma crítica comparativa: Euclides da Cunha.

Com o objetivo e a pretensão de não só identificar, mas principalmente de firmar os princípios estilísticos que deveriam nortear uma adequada produção literária referente à Amazônia, o crítico amazonense buscou fundamentar o seu argumento no reconhecimento necessário que deveria prevalecer nas distintas obras e, por consequência, ser percebido pelos diferentes autores: a predominância de uma dupla imposição e bem medida oscilação entre, primeiro, a importância capital a ser conferida ao papel da imaginação como chave de compreensão da singularidade regional e, segundo, o imperativo do apego aos dados de realidade então indispensáveis para um diagnóstico mais eficaz dos problemas reclamados pela região.

Ora, o ponto de partida por ele tomado já demonstrava, assim, qual a importância até então assumida por Euclides da Cunha como um autor crucial para o desvelamento dos sertões brasileiros, aí incluída a paisagem natural e social da Amazônia. Todos os autores e obras listados e analisados por Péricles Moraes estão direta e indiretamente comparados ao estilo dos escritos relativos à Amazônia do autor de Os sertões.

Já quanto aos autores e obras anteriores ao prosador de $\grave{A}$ margem da história, segundo os argumentos do crítico, coube a eles simplesmente a tarefa de representar o papel de precursores que tatearam e não lograram revelar por inteiro uma realidade marcada pelo caráter ímpar da sua natureza. É nesse sentido, por exemplo, que Péricles Moraes confere ao Barão de Sant'Ana Nery e ao seu livro O país das Amazonas uma importância menor, mesmo que tenha sintetizado, de alguma forma, todos os ganhos científicos e literários até então conquistados. No entanto, em 
função de o livro ter sido composto por dados e argumentos coligidos de outros autores e obras, ele peca pela ausência completa da observação direta por parte do próprio autor. Como já fora ressaltado pelo crítico, juntar um pendor literário e dados de realidade configurava-se em princípio estético indispensável para pensar a Amazônia. Para Péricles Moraes, o único a ter alcançado tal mérito foi justamente Euclides da Cunha.

\section{O inferno de Alberto Rangel}

Tomado, portanto, como uma espécie de cânon da interpretação regional, Euclides da Cunha é explicitamente referido pelo crítico amazonense como portador de um estilo ao qual a maioria dos autores tentou seguir, a despeito das notórias dificuldades implicadas e dos consequentes riscos de insucesso:

De fato, naquela época, a não ser o prosador d'Os sertões, nenhum outro escritor se aventurou à temeridade de tais entrepresas. Pode-se mesmo avançar que os seus estudos sobre a Amazônia, assim nas páginas do À margem da história, como no prefácio magistral do Inferno verde, são o eixo central de tudo quanto se tem pensado e escrito sobre a região portentosa. Euclides, com a sua faculdade de ver, compreender e deduzir tinha ainda a vantagem de possuir uma sensibilidade aguçadíssima, que Ihe transmitia às imagens as vibrações do temperamento ensofregado. A natureza por ele objetivada, sendo exatamente a mesma que servira às lentes dos outros escritores e cientistas, parece-nos, entretanto, agitada pelos fluxos e refluxos de uma imaginação ardente, que poreja sangue e Ihe dá a medida, a extensão e a superioridade do espírito. (Moraes, 2001, p. 15) (grifos meus)

Nesta passagem, é possível aquilatar o grau de importância e o papel conferidos por Péricles Moraes à prosa de Euclides como o estilo mais adequado para o alcance de uma síntese pertinente das dimensões natu- 
ral e social da região. Os diversos e pequenos textos escritos pelo autor de Os sertões acerca da Amazônia teriam condensado de forma harmônica o seu quadro social e natural, com todas as peculiaridades implicadas. Também merece destaque por parte do crítico o "prefácio magistral" de Euclides ao livro de Alberto Rangel, Inferno verde, então avaliado como um momento de fundação e definição dos princípios e rumos a serem seguidos por uma criação literária regional. (Prefácio este, vale ressaltar, que fora enviado por Euclides da Cunha ao autor de o Inferno verde em 27 de agosto de 1907, conforme carta endereçada ao contista [cf. Galvão \& Galotti, 1997, p. 337], portanto, antes da publicação dos escritos de Euclides referentes à sua aventura amazônica.)

Os argumentos presentes no preâmbulo do livro de Alberto Rangel, na realidade, sintetizam tudo aquilo que já havia sido esquadrinhado no espírito do autor de Contrastes e confrontos sobre a Amazônia e que logo em seguida seria publicado nos seus escritos póstumos: um espaço impossível de ser apreendido em seu conjunto e de uma só visada $(O$ seu espaço é como o espaço de Milton: esconde-se em si mesmo), sendo necessário, para tal, um longo percurso de pesquisas na área das ciências naturais; a crença no fechamento da própria história natural quando do completo deslindamento da realidade amazônica; o caráter ainda informe da natureza, sendo a região considerada, por isso, a última página do Gênesis a ser escrita (cf. Rangel, 2001, p. 23-4).

Porém, o que mais chamou a atenção de Euclides da Cunha nos contos de Inferno verde, e que fora totalmente desconsiderado pelo crítico amazonense em seu ensaio, foi a capacidade artística atingida pelo também escritor/engenheiro Alberto Rangel em expressar de maneira adequada o caráter vivificante da natureza amazônica. Apesar de algumas ressalvas aqui e ali, o mérito do livro residia, segundo o juízo de Euclides, no papel central conferido a uma natureza "pré-diluviana" e, como con- 
sequência, no papel determinante que essa mesma natureza exercia no comportamento das personagens dos diversos contos. $\mathrm{O}$ fato de o autor dos contos ter-se aferrado a pequenos quadros, nos quais as várias e curtas histórias se desenrolam, não escapou à argúcia do prefaciador ao identificar nessa estratégia certa pretensão em alcançar uma visão totalizadora de uma realidade que não se deixa jamais apreender.

Ora, os princípios delineadores de uma criação literária acerca da Amazônia já estavam fixados pelo autor de $A$ margem da história e não eram passíveis de modificação. Se a cada conto o intento artístico e literário atingia aquela singularidade quase inexprimível de uma natureza opressora, a perspectiva de conjunto do livro, com a junção dos diferentes quadros, não fornecia uma visão convincente da complexidade da paisagem regional. Para Euclides da Cunha, portanto, tudo deveria ocorrer dentro de um necessário rebatimento do espaço geográfico da região sobre a própria fatura artística da obra. No detalhe e em cada conto de Inferno verde o ambiente hostil da natureza amazônica apresenta-se em permanente atuação sufocante sobre a vida das personagens; já no seu conjunto, no entanto, tal percepção desvanece-se.

Foi precisamente a partir destes parâmetros de fatura e criação literária que Péricles Moraes, anos depois, pretendeu desfiar toda aquela série de autores e obras que haviam se voltado para a Amazônia com o fito de representá-la. Armado com os ensinamentos do prosador de Os sertões e com a mira voltada para cada obra, o crítico amazonense empreendeu em seu ensaio a classificação de cada autor conforme se aproximasse ou se afastasse do estilo por ele tomado como canônico. Neste diapasão, no entanto, segue-se de imediato (o que não deixa de ser um paradoxo) a avaliação negativa daquele que viria a ser considerado pelo crítico como o primeiro a tentar seguir o estilo já esboçado por Euclides: Alberto Rangel. Ele é de chofre retratado como um imitador da prosa de 
Euclides da Cunha e, conforme o vaticínio do crítico, como que impossibilitado de atingir o mesmo nível de gênio desse último, não consegue ver a mesma região:

Já o sr. Alberto Rangel, escrevendo num estilo rígido, inquieto e castigado, onde se encontram, não raro, os relevos violentos e as descargas nervosas do estilo de Euclides, sem medir as perspectivas cheias de seduções e de perigos que se abriam diante de sua imaginação, viu a Amazônia de outro modo. (Moraes, 2001, p. 20) (grifos meus)

E, dessa impossibilidade de seguir de perto a prosa vigorosa de Euclides, a obra mesma era apresentada como defeituosa e falsificadora no que dizia respeito à realidade amazônica, além de carente de uma presença autoral precisamente por estar escorada em observações de outros escritores:

Eriçada de impropriedades, tumultuária de lances enfáticos, desbordante de imagens excessivas e incoerentes, congestionada de narrações prosaicas e de aflitiva monotonia, que lhe acusam a erudição superficial e discursiva, a obra ressentese, desde logo, das fraquezas e debilidades do escritor, apresentando uma Amazônia absurda, falsa e mistificada, erigida sob os auspícios da observação de outros escritores e, por conseguinte, sem o cunho da visada pessoal, que imprimiria, pelo menos, o caráter de autenticidade a certas invenções porventura mais fantasiosas. (Moraes, 2001, p. 21)

A despeito do balanço positivo do próprio Euclides da Cunha ao prefaciar o livro de Alberto Rangel, o crítico não se acanha em identificar os pontos por ele considerados fracos no conjunto da obra. Essa sua pretensão de apreender os aspectos estritamente estilísticos da fatura do livro redundou em cegueira daquele outro aspecto então salientado pelo próprio Euclides: a revelação adequada, em cada quadro, de uma natureza viva e que se apresentava de um modo esmagador frente ao elemento humano. A preocupação excessiva em identificar o estilo e, por conseguinte, compará-lo ao modelo canônico euclidiano, fez com que Péricles Moraes 
cumprisse, na realidade, o simples papel de denunciador dos impostores e imitadores do estilo alheio.

Essa pecha de "imitador mal-sucedido", no entanto, foi imediatamente refutada pelo próprio autor de Inferno verde no mesmo ano de lançamento do livro do crítico amazonense. De Paris, onde então residia, Alberto Rangel enviou uma carta a Péricles Moraes reclamando o seu quinhão de autoria e recusando-se a simplesmente cumprir o papel coadjuvante de um imitador:

A propósito do pouco que se cabe na quota de minha modesta atividade literária e do que é devido ao ingente e inolvidável Euclides, não the parece ter havido uma espécie de conspiração para me reduzir a um simples percevejo do lombo euclidiano? O fato do homem de Os sertões ter prefaciado o insignificante Inferno verde, colocou-me no frontispício a etiqueta de seu imitador. É base, meu prezado confrade, quanto esforço é preciso entre nós para romper a comodidade de certos assertos (sic). Até hoje não surgiu ainda um crítico que ousasse dar-me a parte do que literariamente me pertence. (Carta de Alberto Rangel a Péricles Moraes in Revista da Academia Amazonense de Letras, 1959, p. 182-3)

A reclamação e a revolta de Alberto Rangel contra Péricles Moraes, por sua vez, não são infundadas caso consideremos a necessidade de olharmos mais detidamente a obra em si e suas múltiplas determinações, sejam estas intra ou extraliterárias. É fácil e cômodo enfileirar o contista como apenas mais um autor a se colocar no rastro da prosa de Euclides da Cunha, e talvez aí se configure aquela conspiração por ele alegada. Mais difícil e trabalhoso é entender os diferentes constrangimentos e motivações pessoais e sociais por ele sentidas para alcançar algumas das suas resoluções literárias.

Afora o estilo um tanto quanto rebuscado de Alberto Rangel, assim como era o do autor de À margem da história, cabe-nos identificar no livro de contos os acicates dos respectivos delineamentos por ele salientados como relevantes da região amazônica, isto é, o modo pelo qual sua arte 
literária, embora inspirada em Euclides da Cunha, apropriou-se do espaço amazônico e buscou recriá-lo com sua marca autoral. O fato de a armação da obra de Alberto Rangel apresentar-se como um livro de contos suscitou no próprio Euclides da Cunha, já no seu prefácio, a confirmação da sua tese acerca de uma natureza passível de ser conhecida somente aos pedaços, impossibilitada de ser apanhada em seu conjunto a partir de uma visão de sobrevoo. Claro deve estar que a linguagem um tanto ornamental já é um elemento central e indicador daquilo a que se está a narrar.

Devemos considerar, porém, outros elementos que atuam nesse processo de narração de um espaço concebido como "só natureza". O narrador em terceira pessoa dos diferentes contos, por exemplo, e que se encontra presente no livro do começo ao fim, expressa o anseio de alguém que, vindo de fora da região, se propõe a viajar pelo interior amazônico imbuído de uma missão, qual seja, a missão de perquirir e desvelar uma parte fronteiriça e inóspita do Brasil totalmente desconhecida: o sertão amazônico. Do primeiro ao último conto, a presença desse narrador em terceira pessoa insinua o tom realista da narração e revela o caráter de viandante do próprio escritor.

Alberto Rangel nasceu na cidade de Recife em 20 de maio de 1871. Após residir em São Paulo durante algum tempo, mudou-se para o Rio de Janeiro onde cursou a Escola Militar da Praia Vermelha. Lá iniciou sua formação em engenharia, concluída no Rio Grande do Sul. Como militar, chegou a participar efetivamente dos combates travados na Revolta da Armada ao lado das forças legalistas. No entanto, em função de desavenças com a instituição militar e descontente com os rumos políticos tomados pela nascente República, desvinculou-se do exército e investiu em uma incerta carreira literária com o lançamento do panfleto Fora de forma e com a publicação periódica de contos em diferentes jornais. Em 1904 transferiu-se para a Amazônia a fim de assumir os cargos de diretor 
de Terras e Colonização e de Secretário Geral do governo do Estado do Amazonas na gestão de Constantino Nery, um dos principais líderes das oligarquias locais (cf. Menezes, 1978, p. 564 e Bittencourt, 1959, p. 65). Após cruzar o Brasil de norte a sul, e seguindo a voga do período, quando diferentes intelectuais buscavam desvendar os sertões brasileiros ${ }^{1}$ (cf. Lima, 1999), não é difícil deduzir o quanto o então pretendente a escritor intentava descobrir o seu próprio país e externar as suas impressões e angústias através da literatura. No entanto, após alguns anos mesclando vida literária e desempenho de funções públicas, Alberto Rangel resolveu ingressar na carreira diplomática, dedicando-se aos estudos e pesquisas históricas em arquivos de países europeus.

Vale notar, porém, o fato de Alberto Rangel não só se mostrar afastado do estilo de Euclides da Cunha, mas também de já explicitar nos seus primeiros contos um interesse pela vida trágica então levada pela população dos sertões brasileiros que, como já ressaltado, revela-se como um dado característico nesse momento de configuração inicial de um campo literário no Brasil. O que também fica patente nessa primeira fase do jovem escritor é a sua preocupação com o fazer literário como um meio de ganhar a vida, de viver profissionalmente como um escritor. Em um momento em que o campo de produção cultural começava a adquirir uma nova dinâmica em função da crescente especialização do trabalho intelectual (cf. Miceli, 2001), esse tipo de preocupação é perfeitamente cabível. É nesse sentido que, já em um dos seus primeiros contos, publicado no jornal $O$ País de 24 de maio de 1896, intitulado "O imaginário", tanto a relação sertão-litoral quanto as questões relativas ao processo de criação artística e literária aparecem como eixos centrais da narrativa (cf. Rangel, s/d, p. 120-70).

1 Em 1913, Alberto Rangel proferiu uma conferência na Biblioteca Nacional acerca dos sertões brasileiros. Cf. Rangel, 1913 p. 108-18. 
O conto retrata o final de vida do já envelhecido entalhador e santeiro Jerônimo. Estabelecido na cidade do Rio de Janeiro e no desempenho do seu penoso ofício de artesão de imagens dos mais diversos santos, as encomendas a ele solicitadas por párocos e fiéis tinham como destino os mais diferentes lugarejos da cidade e do interior. Cada peça deveria ser moldada com certa inventividade dotada do melhor acabamento artístico, além de seguir as recomendações do gosto da clientela. O conhecimento necessário da vida dos diversos santos por parte do entalhador era fundamental como requisito para um acabamento adequado de cada peça. A rememoração do seu deslocamento do interior para a cidade é justamente deflagrada quando lhe é encomendada uma modesta imagem de um crucifixo destinada a um desses longínquos lugares do interior do país. Lá, em pleno sertão, ele havia deixado um dia sua mãe, Macária, e sua namorada, Márcia, com a promessa de voltar assim que tivesse acumulado alguma riqueza na cidade. Como nunca havia conseguido acumular riqueza alguma, esse tempo fora permanentemente adiado.

Com esse entrecho, o conto desdobra-se, assim, em outras relações paralelas àquela de sertão-litoral, como, por exemplo, lavoura-artesanato, sagrado-profano e, por fim, paraíso-inferno. O exercício do ofício de entaIhador de santos já o coloca nesse meio-termo entre o sagrado e o profano. As imagens entalhadas são destinadas ao culto religioso, mas, por outro lado, devem ser comercializadas como uma mercadoria qualquer. Já a atividade de artesão na cidade em nada se assemelha à atividade da lavoura no campo. Lá o cultivo da terra obriga o lavrador a uma obediência ao ritmo da natureza. Na cidade, por sua vez, o tempo desprende-se da ordem natural e segue o ritmo do trabalho então imposto pelo próprio artesão, conforme o volume das encomendas. E dessa discrepância existente nos modos de vida no campo e na cidade emergem representações do sertão com contornos de um quase idílio por parte de quem habita o meio urbano. 
A perturbação que aquelas memórias da mãe e da antiga namorada Ihe causam chega ao clímax justamente quando do término da feitura da tal imagem encomendada e no momento preciso de pregá-la na cruz. $\mathrm{O}$ velho entalhador sofre alucinações de tal ordem que o colocam, nesse momento de agonia e morte, em uma encruzilhada onde as oposições entre o bem e o mal, o paraíso e o inferno, apresentam-se na forma de espectros. De um lado, sua mãe Macária representando o "amor celestial", o "amor puro" (o próprio nome "Macária" não deixa de fazer uma alusão direta à obra de Álvares de Azevedo, logo, ao romantismo). De outro, Márcia, sua namorada e amante lasciva, uma referência ao "amor carnal".

Ora, a temática sertaneja já aparecia, portanto, como uma das preocupações literárias de Alberto Rangel antes mesmo de qualquer influência de Euclides da Cunha. Ele seguia, como sabido, a voga regionalista do final de século XIX que assolava a produção literária nacional (cf. Leite, 1994). E é nesse sentido que a relação inferno-paraíso ganha força como explicitação da problemática sertão-litoral e como diagnóstico da realidade brasileira. Não é difícil deduzir o fascínio que para o jovem escritor significava uma região como a Amazônia. Mas a contraposição presente no entrecho do conto entre as personagens Macária e Márcia, por seu turno, expressa ainda a condição incerta do ofício de escritor em um momento de indefinição do trabalho intelectual. $\mathrm{O}$ entalhador de santos sucumbe perante as duas imagens que o alucinam, indeciso quanto ao rumo a seguir no momento de agonia. O "amor puro" e o "amor carnal" (e que poderíamos denominar também como mercenário) implicam duas formas distintas de expressar o fazer artístico-literário e que tendem a polarizar a própria estrutura do campo de produção simbólica (cf. Bourdieu, 1996). Não há, portanto, nem mercado e nem mesmo um polo autônomo de produção literária em condições de sustentar materialmente os aspirantes a escritor. O mercado de 
cargos públicos e a atividade jornalística é que desempenham a função de subsidiar, de alguma forma, a produção literária.

É possível estabelecermos dois eixos distintos e complementares de abordagem de Inferno verde: primeiro, a partir de uma perspectiva horizontal, identificamos um desdobramento narrativo dos diferentes contos na medida em que o mesmo narrador, ao se deter nas diversas histórias então ambientadas em um mesmo cenário de selva, insinua uma gradual inserção no espaço amazônico através do engate de um conto no outro. Tudo se passa como se no conjunto dos contos, tomados cada um como andaimes de uma construção, o edifício de um possível romance estivesse latente. Nessa viagem rumo ao desconhecido, também é identificável, em meio a uma natureza sempre presente em exagero e delineada de um modo hostil e sufocante, um conflito de ordem social travado entre o elemento nativo, o caboclo, e os "intrusos", fossem estes os "cearenses" (incluídos todos os nordestinos para lá migrados) ou indivíduos oriundos de outras partes do país. Esse conflito, por seu turno, ocorre sempre à sombra daquela que se converte ao longo da obra na principal personagem: a natureza amazônica. É sempre ela quem, nos desfechos dos contos, ou se alia ao elemento nativo contra o invasor, ou se torna o refúgio e referência dos "fracos" (caboclos) perante o poder dos "fortes" (aventureiros/ádvenas). A presença da natureza, portanto, se dá ora através da sua participação direta nos diferentes episódios, ora através da sua descrição minuciosa como cenário propício para o desdobramento das diversas atrocidades e desmandos sociais que lá ocorrem, favorecendo, assim, um traço trágico e horrendo ao conjunto da obra.

No entanto, tomando-se uma segunda perspectiva analítica, e seguindo uma linha vertical, a relação entre natureza e cultura surge como o fulcro central de todas as tramas contidas no livro, o que, por seu turno, acaba por conferir à obra não só uma unidade, mas também uma organi- 
cidade ao seu conjunto na medida em que propicia uma interação entre as suas diversas histórias. Pode-se dizer, neste sentido, que Inferno verde está filiado, enquanto fatura literária, à proposta estética do naturalismo prevalecente no final do século XIX e início do século XX. A noção geral de que a Natureza (com "N" maiúsculo) é portadora de um caráter indômito e que, por seu turno, tende a açambarcar de maneira voraz os diferentes indivíduos, interferindo em seus respectivos comportamentos em sociedade, acaba por ser tomada no livro como a ideia motriz a estimular o processo criativo do autor. Não há descrição de qualquer aspecto social das vivências regionais que não estejam referidas, direta ou indiretamente, ao ambiente natural da região. Desde o primeiro conto, "O Tapará", em que o modo de vida penoso de uma família de caboclos é retratado conforme a descrição minuciosa da fauna em agonia aglutinada ao redor de um lago pútrido e em processo avançado de vazante, até o último, "Inferno verde", no qual a própria selva manifesta-se como uma personagem com voz ativa encarregada de expulsar os intrusos, a confrontação que prevalece no livro é sempre entre natureza e cultura²

Mesmo quando os confrontos de ordem eminentemente social narrados nos contos tendem a ressaltar a discrepância entre o grau de forças distintas das ações de uns e as reações de outros, tal enfrentamento é sempre expresso pela alusão direta ao modo supostamente peculiar da natureza amazônica configurar-se. No conto "Obstinação", por exemplo, o conflito entre o caboclo Gabriel, um pequeno proprietário de terras, e Roberto, "cearense" tornado um grande latifundiário após a sua chegada à região, toma como referência o modo pelo qual a própria natureza

$2 \mathrm{O}$ conceito de cultura deve ser entendido aqui como uma categoria autônoma em relação à ideia de natureza. Conforme demonstrado por Raymond Williams, no bojo da tradição literária inglesa, o conceito de cultura inicialmente encontrava-se preso à concepção de natureza e, paulatinamente, desprendeu-se dela e ganhou valor heurístico próprio no decorrer das modificações materiais da sociedade. Cf. Williams, 1969 e 2000. 
amazônica expressa essa confrontação: o apuizeiro, uma espécie de planta parasita, suga e constrange até a morte o abieiro, a árvore parasitada. Esse recurso adotado pelo narrador ao longo da obra justifica-se, por um lado, pela necessidade de expressar de modo dramático essa luta desigual entre um forte e um fraco. Mas, por outro, essa "linguagem verde" então em voga entre diferentes e variados autores desse período não dava margem a alternativas estilísticas quanto à maneira de descrever a Amazônia.

O escritor paraense Raimundo Moraes, por exemplo, mesmo adotando uma perspectiva oposta a de Alberto Rangel quanto à representação literária da Amazônia, também se vale desse recurso expressivo de uma "linguagem verde". Com propósitos distintos do contista, o autor paraense também faz referência ao apuizeiro no seu livro Na planície amazônica, publicado em 1926. Com o objetivo de explicitar a possibilidade de vitória de um ser fraco contra outro forte, Raimundo Moraes lança mão do exemplo do apuizeiro como metáfora dessa improvável luta entre forças tão desiguais:

O apuizeiro, de tamanho reduzido, a brotar da entrecasca, da coroa, do nódulo, da forquilha, de qualquer parte enfim da árvore onde a terra, levada pelos alísios e pelos pássaros, tenha formado um pequenino vaso de madeira viva - assemelha-se a qualquer raminho inocente, obra ornamental e decorativa da jardinaria japonesa. Camuflado de arbusto, aparentemente fraco, sem a menor importância, o perigoso inimigo não deixa adivinhar a rijeza tremenda de suas antenas, a ação envolvente e compressora de seus fios maraviIhosos, plásticos, estranguladores. (Moraes, 1987, p. 102-3)

A presumível inocência da pequena planta de aparência ornamental guarda em si mesma a força que irá estrangular e ameaçar as demais árvores da selva. No argumento de Raimundo Moraes, o apuizeiro é muito mais uma referência a um possível poder nativo do que símbolo de força do intruso, como em Alberto Rangel. Para este, assim como o apuizeiro 
é uma planta parasita que sobrevive em função da seiva então fornecida pela árvore parasitada, fincando as suas raízes de predador vegetal, o "cearense" desenraizado aproveita-se dos vínculos e raízes do caboclo com a sua terra para acumular mais riqueza. É uma denúncia política e, conforme o autor, quase uma constatação sociológica: o aventureiro enriquece via a exploração dos nativos. Essa diferenciação de posturas literárias entre Alberto Rangel e Raimundo Moraes, a despeito da partilha de uma mesma linguagem, indica o grau de afastamento possível de ser detectado entre ambos. Visões distintas a expressar constrangimentos variados quanto ao processo de criação literária.

O enredo do conto segue um balizamento fornecido por pares opostos nos quais a esfera da natureza complementa e ilumina o entendimento da esfera social. De um lado o enraizamento do caboclo Gabriel frente o desenraizado Roberto, de outro, a imagem respectiva desse conflito espelhada pela própria natureza: o apuizeiro a sugar toda a seiva do abieiro. Quando a vítima do conto se apercebe da sua impotência frente o poder do seu algoz, acaba por se deparar com um abieiro já em frangalhos e praticamente morto em função da ação detratora do apuizeiro:

O apuizeiro é um polvo vegetal. Enrola-se ao indivíduo sacrificado, estendendo sobre ele milhares de tentáculos. O polvo de Gilliat dispunha de oito braços e quatrocentas ventosas; os do apuizeiro não se enumeram. Cada célula microscópica, na estrutura de seu tecido, se amolda numa boca sedenta. E é a luta sem um murmúrio. Começa pela adaptação ao galho atacado de um fio lenhoso, vindo não se sabe donde. Depois, esse filete intumesce, e, avolumado, se põe, por sua vez, a proliferar em outros. Por fim, a trama engrossa e avança constrangente, para malhetar a presa a que se substitui completamente. Como um sudário, o apuizeiro envolve um cadáver; o cadáver apodrece, o sudário reverdece imortal. O abieiro teria vida por pouco. Adivinhava-se um esforço de desespero no mísero-enleado, decidido a romper o laço da distrição, mas o manietador parecia fazer-se mais forte, 
travando com todas as fibras constritivas o desgraçado organismo, que o arrocho paulatino e inaudito ia estrangulando. E isto irremediavelmente. Com um facão poder-se-ia despedaçar os tentáculos e arrancá-los. Bastaria, porém, deixar um pequeno pedaço de filamento capiláceo colado à árvore, para que, em renovos, o carrasco reacometesse a vítima, que não se salvaria. O pólipo é um polipeiro. Vivem gerações num só corpo, numa só parte, numa só esquírola. Tudo é vida por menor que seja o bloco. Não há reduzi-la a um indivíduo. É a solidariedade do infinitamente pequeno, essencial, elementar, inseparável na república dos embriões sinérgicos. $O$ que fica, basta sempre à revivescência, reproduz-se fácil, na precipitação latente e irrefreável de procriar sempre.

A copa de pequenas folhas coriáceas e glabras do abieiro sumia-se, quase, na larga folharia da parasita monstruosa.

Representava, na verdade, esse duelo vegetal, espetáculo perfeitamente humano. Roberto, o potentado, era um apuizeiro social... (Rangel, 2001, p. 108-9)

Da relação entre força e fraqueza contida na luta surda travada entre o apuizeiro e o abieiro desdobra-se outra relação insinuada pelo narrador, esta, por sua vez, tomada como pretensa explicação e justificação das distintas motivações subjacentes e atuantes no "cearense" aventureiro e no caboclo acomodado e impotente. O regime de seca característico da região nordestina é tomado como um dos fatores causadores da miséria que a tudo dizima, é o mundo originário do "cearense" Roberto. O seu instinto de sobrevivência em um meio tão adverso como aquele seria o responsável pela formação de seu caráter e pela sua avidez em acumular riqueza. Já a Amazônia, caracterizada como uma região úmida e dotada de recursos tão abundantes, seria, por seu turno, a causa última da completa ausência de ambição na personalidade do velho caboclo Gabriel que, ao receber de herança um pedaço de terra, continuava a ocupar a mesma posição social de seus antepassados. O desfecho do conto acentua ainda mais estes rebatimentos entre a esfera da natureza e a esfera 
social. Quando Gabriel perde definitivamente sua pequena propriedade para o ambicioso Roberto, ele toma a atitude extrema e emblemática de enterrar-se no terreno úmido de sua pequena propriedade. Essa atitude de desespero do caboclo Gabriel é, a um só tempo, símbolo de resistência perante o intruso/parasita e expressão máxima de seu acolhimento pela natureza na medida em que esta se transmuda de berço em túmulo.

A partir do entrecho do conto, a própria região amazônica aparece não só como uma natureza ainda informe, mas também, e correlativamente, como uma sociedade em processo de formação. Essa sociedade talvez só germine a partir dessas ações extremadas de resistência: o caboclo Gabriel transforma-se em uma espécie de "semente" no solo úmido em que se enterra.

Note-se, entretanto, que os limites entre natureza e cultura são estabelecidos na urdidura da obra tendo em vista a prevalência do primeiro polo em relação ao segundo. Essa predominância de um aspecto sobre o outro é expressa pelos critérios e princípios oriundos de uma presença excessiva da natureza então tomada como in natura em uma região onde a civilização se mostra ainda escassa. A linha divisória entre um campo e outro é traçada conforme as balizas de uma suposta natureza que, desbragadamente, engolfa os modos de viver e os modos de pensar da sociedade malformada. É como se o autor estivesse a dizer que a realidade deste "mundo amazônico" só pudesse ser transfigurada em termos ficcionais lançando-se mão dos próprios parâmetros do ambiente de selva que a tudo domina. Como o traço característico e marcante da Amazônia sempre esteve estribado nas peculiaridades da sua fauna e flora, e isso desde os primeiros relatos de viajantes e exploradores, a natureza tende a prevalecer no conjunto dos contos de Alberto Rangel ou como a grande heroína, ou como a personagem central do começo até o final. 
Mas também nos cabe aqui indagar acerca das motivações extraliterárias que levaram o autor a pintar a região nesses tons e termos. Suas filiações a outros autores portadores de um "nome próprio" (Euclides da Cunha) já demonstravam não só as suas opções e esforços estilísticos de per $\mathrm{si}^{3}$, mas também os prováveis lucros por ele almejados em um campo literário ainda malformado. Seus vínculos com a elite regional também não devem ser desconsiderados ou diminuídos frente os ajustes de fatura literária então alcançada. É nesse sentido, por exemplo, que se faz presente no livro certo maniqueísmo do autor quando retrata a população cabocla da região sempre em condições precárias e desvantajosas em relação ao intruso. Esse elemento intruso, por seu turno, fosse ele o nordestino migrado, fosse ele qualquer outro aventureiro oriundo de outra parte do país, é convertido nos contos que compõem o livro em uma espécie de causa do atraso vivenciado pela região, além de simbolizar o arrivismo reinante ao longo desse período do boom de exploração da borracha.

Para Alberto Rangel, portanto, a Amazônia sofria dos males dos aventureiros de toda ordem que então se dispunham a lançar mão de todos e quaisquer meios para acumular riqueza. No entanto, ressalte-se o completo silêncio do autor quanto ao papel da elite regional dominante. Esses estratos sociais dirigentes encontram-se completamente ausentes dos distintos entrechos dos contos que compõem a obra. Esse silêncio, por si só, já é bastante revelador dos vínculos tácitos firmados entre o autor e seus respectivos contratantes como funcionário graduado da administração pública, vínculos estes que, ao fim e ao cabo, acabaram por atuar e interferir, de uma forma ou de outra, nas diferentes opções de criação literária. A presença de um maniqueísmo extremado nos diver-

3 Em uma conferência realizada em agosto de 1913, Alberto Rangel defendeu publicamente o estilo de Euclides e, com isso, reforçou a sua própria adesão ao nome do autor de Os sertões. Ver Rangel, 1916, p. 26. 
sos contos e, sintomaticamente, a descrição do apuizeiro estrangulando/ constrangendo o abieiro, são sintomas dessas interferências.

Mesmo as críticas mais contundentes em relação ao processo de extração e produção da borracha presentes no Inferno verde não incluem os setores dirigentes da região, aos quais o autor se encontrava atrelado. O foco das críticas recai sempre sobre os donos dos seringais, os seringalistas. Estes eram, invariavelmente, ex-seringueiros nordestinos que conseguiram, de uma forma ou de outra, acumular alguma riqueza e acabaram por se tornar proprietários de seringais. A irresponsabilidade e a ganância desses agentes sociais, juntamente com a configuração da natureza, segundo Alberto Rangel, eram as maiores causas do atraso civilizatório na região. Ora, o autor não conseguia atinar para o fato de que toda a riqueza desfrutada pela pequena camada social que vivia aos modos europeus nas cidades de Manaus e Belém, e que então controlava politicamente a região, advinha exatamente da exploração extremada levada a cabo pelos mesmos seringalistas gananciosos nos vários recônditos da Amazônia. As relações sociais que embasavam todo o processo produtivo da goma elástica estavam assentadas, conforme ressaltará depois Euclides da Cunha, na barbárie de relações sociais quase escravistas de exploração. Nesse caso, como se nota, o epígono estava impossibilitado de seguir o seu mestre, constrangido pelos seus laços empregatícios.

No conto "Maibi" o autor tenta fornecer, a partir da composição de um quadro alegórico, todos os mecanismos atuantes nesse processo de exploração levado a cabo por seringalistas gananciosos e seus respectivos efeitos deletérios para a região. Nele se faz presente não só a figura do seringalista, sempre preocupado com a cotação do preço da borracha e com o aumento dos seus lucros, mas também aparecem os diferentes seringueiros que compõem o conjunto de empregados do seringal. Entre estes, por sua vez, diferenciam-se aqueles que possuem saldo maior ou 
saldo menor na contabilidade viciada do patrão. A busca de um saldo cada vez maior é o objetivo a ser alcançado pelos seringueiros, pois só assim seria viabilizado o fim daquele isolamento e aprisionamento sofridos fosse pela ação da natureza, fosse pelas amarras das relações sociais injustas que caracterizavam os seringais. Conforme salienta o autor, relações sociais estas que punham em dúvida não só a própria ideia de uma nação livre, mas também a eficácia do Estado brasileiro de estender-se com todo seu aparato burocrático ao conjunto do país. A Amazônia, dessa forma, dada a sua especificidade, acabava por exigir ações urgentes perante as atrocidades cometidas nos seringais.

Esse isolamento sofrido pelo seringueiro nos confins da Amazônia era invariavelmente atenuado pela presença rara de uma mulher junto a si em sua localidade. Mas somente os seringueiros com bom saldo poderiam dar-se a esse luxo. No conto de Alberto Rangel, Sabino negocia com o seringalista Marciano a sua mulher Maibi pela quitação de seu saldo, até então negativo. Ela, Maibi, iria agora morar com outro seringueiro possuidor de saldo suficiente para cobrir o déficit de Sabino. Uma operação contábil a um só tempo simples e macabra, já que reveladora do grau de comercialização que afetava as relações sociais na região. Era o capital impondo a sua lógica. A cabocla Maibi tornou-se, como poderiam tornar-se todas as poucas mulheres que viviam espalhadas pelos seringais naquele período, moeda de troca entre seringueiros e seringalista. Só que o sentimento de solidão de Sabino não poderia ser resolvido, ou mesmo arrefecido, por uma simples operação de contabilidade que inverte os sinais de negativo em positivo. Seus sentimentos pela cabocla Maibi também não seguiam a lógica e a racionalidade do passivo igualando-se ao ativo. Em uma atitude de desespero que deixa transparecer a irracionalidade daquele cotidiano, Sabino resolve tomar Maibi de volta e matá-la de uma forma brutal. Transforma a cabocla em uma espécie similar de 
seringueira ao amarrá-la a uma árvore e encaixar pequenas tigelas em seu corpo, tigelas estas então utilizadas para recolher o látex. Só que ao invés de látex, o sangue é que jorra:

Atado com uns pedaços de ambécima à "madeira" da estrada, o corpo acanelado da cabocla adornava bizarramente a planta que Ihe servia de estranho pelourinho. Era como uma extravagante orquídea, carnosa e trigueira, nascida ao pé da árvore fatídica. Sobre os seios túrgidos, sobre o ventre arqueado, nas pernas rijas, tinha sido profundamente embutida na carne, modelada em argila baça, uma dúzia de tigelas. Devia o sangue da mulher enchê-las e por elas transbordar, regando as raízes do poste vivo que sustinha a morta. Nos recipientes o leite estava coalhado - um sernambi vermelho ...

Tinha esse espetáculo de flagício inédito a grandeza emocional e harmoniosa de imenso símbolo pagão, com a aparência de holocausto cruento oferecido a uma divindade babilônica, desconhecida e terrível. É que, imolada na árvore, essa mulher representava a terra...

O martírio de Maibi, com a sua vida a escoar-se nas tigelinhas do seringueiro, seria ainda assim bem menor que o do Amazonas, oferecendo-se em pasto de uma indústria que o esgota. A vingança do seringueiro, com intenção diversa, esculpira a imagem imponente e flagrante de sua sacrificadora exploração. Havia uma auréola de oblação nesse cadáver, que se diria representar, em miniatura um crime maior, não cometido pelo Amor, em coração desvairado, mas pela Ambição coletiva de milhares d'almas endoidecidas na cobiça universal. (Rangel, 2001, p. 135) (grifos meus)

Maibi encarnava, portanto, e de um modo alegórico, a própria Amazônia na medida em que a sua vida era sacrificada em nome de uma ambição coletiva. O paralelismo entre a seiva fornecida pela seringueira e o sangue a jorrar do corpo de Maibi presa ao pé de uma árvore, tal qual uma orquídea que ali floresce, só reforça o esquema adotado pelo autor de o Inferno verde: a natureza como parâmetro explicativo da realidade 
social. A ambição levaria à morte da própria região caso nada fosse feito para deter a ganância dos seringalistas. Alberto Rangel estava impossibilitado de perceber que a ganância não estava somente na figura abjeta do seringalista, mas também se encontrava, principalmente, naqueles mesmos dirigentes políticos que o contrataram e que viabilizaram, em última instância, o seu investimento literário. Investimento literário que estava, tal como Maibi, enlaçado por teias sociais constritoras.

Como demonstrado na análise dos contos "Obstinação" e "Maibi", a maneira mais proveitosa de solucionar a complexa equação entre texto e contexto de uma determinada obra dá-se, inicialmente, a partir de uma análise da obra em si mesma, buscando identificar, quando possível, seus vários aspectos estruturantes e, assim, levar em consideração as suas respectivas partes e o todo autônomo daí composto. Em combinação com o seu contexto, a obra, dentro da sua urdidura específica, fornece os elementos que expressam motivações outras atuantes no processo criativo do autor. O último conto do livro, por exemplo, cujo título "Inferno verde" acaba por dar nome ao livro, é expressivo não só dos vínculos do então engenheiro Alberto Rangel com a região, mas também da sua concepção política e literária quanto ao papel do sertão amazônico dentro do panorama nacional.

Trata-se da história de Souto, um engenheiro e ex-militar, tal como o escritor, a serviço do governo local com a missão de demarcar um determinado conjunto de terras no interior não desbravado desse sertão verde. Utilizando-se do único meio de transporte possível de ser manejado naquele espaço geográfico singular, a canoa, e assessorado nessa empreitada por conhecedores do ofício de navegar e desbravar ermos (o taciturno caboclo Miguel, o falante "cearense" Simeão e o mulato Chico Brabo), o jovem engenheiro inicia um trajeto de confronto íntimo de estrangeiro com a sufocante natureza que então o cerca. 
Adentrando paragens até ali pouco ou jamais visitadas por outros viajantes com o intuito de fazer medições e demarcações, o jovem engenheiro sentia-se, desde a sua chegada, solitário e abandonado em uma região onde a natureza ainda impunha o seu ritmo de vida, sobrepondose, inclusive, ao poder da máquina a vapor. A "sociedade das máquinas", símbolo da civilização moderna, ainda não era capaz de vencer aquele espaço onde a natureza reinava:

Uma nódoa acinzentada, que de repente se apagou aos silvos, obumbrando-se no punhado luxuriante das canaranas, sororocas e embaúbas, era o "gaiola" que deixava Souto no alto Juruá, desterrado para a luta, na delirante vida de explorar um sertão. O xaveco voltava precipitadamente. Tinha sido o último a subir, em arrojo imprudente. Apressara-o, portanto, o medo de permanecer pela vazante rápida, espetado no tronco de piranheiro, ou embicado no tijuco de alguma praia. Se isso acontecesse, ficaria como o Souto, esperando a volta da enchente para descer a Manaus. E o que era ganho e fortuna para o engenheiro, prejudicaria ao armador... (Rangel, 2001, p. 147)

A imagem do navio em partida apressada e o conhecimento da impossibilidade de sua volta antes de um novo período de cheia do rio causam no jovem engenheiro a sensação de esquecimento e de abandono de seu próprio mundo. Mas a sua presença ali naqueles ermos não é gratuita. Contratado para cumprir o seu ofício, o "deserto verde" converte-se para ele em fonte de renda. A Amazônia, dessa forma, e por ser ainda um espaço inexplorado, abria-se aos diferentes ádvenas, fossem arrivistas ou não.

Após o início da sua incursão pelo intricado da vegetação da selva, o jovem engenheiro, por meio do narrador, exterioriza a sua impressão daquela paisagem a um só tempo deslumbrante e sufocante, que a tudo envolve como um grande invólucro.

Foi assim, entre o silêncio respeitoso do Miguel e a palrice dos outros homens, que Souto chegou a uma barraquinha 
deserta, abafada entre velhas pacoveiras. O bananal apertava a barraca; a floresta sufocava o bananal; e, por sua vez, o céu esmagava a floresta. Foi esse o primeiro pouso do Souto, no remoto confluente do Solimões (Rangel, 2001, p. 151)

Quando a pequena comitiva por ele chefiada resolve pernoitar em uma pequena cabana abandonada em plena selva, próxima a uma área pantanosa e pútrida, ambiente hostil a qualquer forma de vida, lá no interior do casebre ele encontra um exemplar do livro A carne, de Júlio Ribeiro. Como à noite os sons da floresta amazônica são perturbadores para ouvidos estrangeiros, diz o narrador, ele, o engenheiro, resolve combater sua insônia e sua angústia de um quase exilado e fugir àquela sensação de morte com a leitura do livro defeituoso do gramático (Rangel, p. 153). Livro este, por sinal, ambientado em um cenário completamente diverso daquele no qual o jovem viajante se encontrava: lá era a natureza paulista, aqui é a natureza amazônica. Se o Brasil sempre foi caracterizado e representado desde o romantismo como um mundo só natureza (cf. Süssekind, 1990), suas diferentes regiões devem ser marcadas e definidas de modos distintos por naturezas específicas.

Enquanto no livro de Júlio Ribeiro a natureza acaba por causar a exteriorização dos impulsos sexuais então latentes na protagonista Lenita, em um claro sinal de manifestação da vida, no conto de Alberto Rangel a natureza se fará presente e atuante no espírito do engenheiro Souto como um elemento a sufocar a própria vida. Não parecia ser suficiente ao autor de o Inferno verde descrever a intrincada natureza amazônica ao modo pretensamente objetivo de um naturalista do século XIX; era necessário expressá-la de outra forma, seguindo, talvez, outra resolução artística extraída das visões atormentadas e subjetivas de alguém diretamente afetado pelo meio.

É sabido que no livro de Júlio Ribeiro existem citações inteiras de diferentes relatos de naturalistas a descrever minuciosamente o ambiente 
então vivenciado pelos personagens com a dupla finalidade de por um lado, ressaltar o caráter nacional (o Brasil é antes de tudo natureza) e, por outro, conferir ao romance um perfil de "quase" ciência (uma exigência da estética naturalista). Já no conto de Alberto Rangel tal estratégia é recusada como recurso estilístico. A saída por ele encontrada se deu pela via problemática de um subjetivismo narrado em terceira pessoa. A natureza seria, assim, descrita e retratada a partir das alucinações sofridas pelo jovem engenheiro ao longo de sua viagem em um meio selvagem, o que reforçaria o aspecto de esmagamento da própria vida.

Enquanto Souto e seus ajudantes passavam a noite naquela tal cabana abandonada e localizada em uma área pantanosa, a natureza hostil da região agia dentro do engenheiro através do mosquito transmissor da malária. A picada do mosquito simboliza, dessa forma, a penetração mortal da natureza no corpo do engenheiro. A partir de então ele começa a ter visões e alucinações perturbadoras causadas pela febre intermitente da maleita. A relação de estranheza que desde o começo da viagem havia marcado a sua presença naquele meio natural sufocante transforma-se em conflito entre o maleitoso e a selva.

Sendo impossível continuar o seu trabalho de medir e demarcar terras em função do progressivo agravamento da febre ocasionada pelo impaludismo, Souto é obrigado a retornar ao ponto de sua chegada na longínqua localidade do Juruá. Se a sua viagem de ida ao interior da selva havia sido marcada por um deslumbramento de visitante em meio a uma natureza intrincada, e que se apresentava como uma contemplação, mesmo que ameaçadora, o seu retorno desse interior mais recôndito ao ponto já conhecido de sua chegada será marcado fortemente por uma natureza agressiva. É como se houvesse no conto dois momentos de enfrentamento entre o engenheiro e a floresta. No primeiro instante, o susto e a sensação de fragilidade de qualquer forma de civilização naquele ambiente que a tudo ameaçava engolfar. No segundo momento, quando a própria natureza, como que cumprindo sua ameaça inicial de a tudo 
engolir, insere-se no corpo e no espírito do engenheiro com a picada do mosquito transmissor da malária, revelando-se mais inteiramente nas alucinações do infectado.

O interessante a se notar, no entanto, é que essa perturbação então causada pelos contínuos delírios febris acabou por fazer com que o jovem engenheiro (e as vozes do narrador e do autor se confundem) explicitasse os seus julgamentos mais íntimos quanto a alguns aspectos da realidade social e política do país. É como se a sua sofrida vivência naquela região esquecida tivesse aclarado no seu espírito os prováveis entraves da própria nação. Isso fica evidente quando, no conto, o jovem engenheiro, e que, como o autor, também fora um militar, vislumbra um acampamento do exército em uma das inúmeras margens dos rios amazônicos. A visão daquela tropa de infelizes cercados pela floresta ameaçadora causa no protagonista certo compadecimento em relação aos soldados. Todos ali reunidos em nome da disciplina e pelo cumprimento de ordens em meio a uma região selvagem, inteiramente fragilizados. Mas é contra os oficiais que a sua voz se dirige. Em uma região como aquela, onde tudo falta em termos de civilização, era inconcebível a politicagem corriqueira na qual aqueles oficiais do exército costumavam se aferrar. E esse juízo parecia expressar os motivos que levaram o próprio Alberto Rangel a desvincular-se do exército.

Não resistindo aos delírios, o engenheiro é acomodado em uma pequena cabana de aparência degradante a fim de descansar da dura viagem de volta. Era a pousada de um seringueiro ausente. Deixado pelo caboclo Miguel, o qual, de modo sempre solícito, sai em busca de ajuda, o doente tem o seu último delírio. A existência de um imenso roseiral cercando a cabana precariamente construída detona a revolta íntima no espírito perturbado do engenheiro. A sua inquietude de solitário em um sertão como aquele faz com que ele busque refúgio nas suas referências mais íntimas então ausentes, ou seja, nos seus familiares e na sua própria terra. Mas a imagem do roseiral imenso a cercar a choupana mal-acabada faz com que essa inquietação se exteriorize em termos acusatórios de 
uma natureza que acolhe uns e rechaça outros. Ela pode apresentar-se como o inferno para alguns e, provavelmente, como o paraíso para outros. Infernal, por exemplo, para ele, representante da civilização que, ao tentar percorrer as entranhas daquela natureza, foi repelido como um intruso. Mas provavelmente paradisíaca para outros, quando providencia aquela paisagem do roseiral para deleite de alguém.

É precisamente durante esse delírio final do engenheiro que o conto atinge o seu desfecho. É aí que ocorre, em meio a esse roseiral bem ajardinado e espinhoso, o seu devaneio tresloucado de lançar-se em uma luta cega com a natureza; é nesse delírio de revolta que a morte o fulmina e as suas últimas palavras resumem-se ao dístico ofensivo à região: inferno verde. Assim que se consuma a morte do engenheiro enlouquecido, a própria natureza amazônica manifesta-se no conto como uma personagem com o objetivo claro de refutar o epíteto lançado pelo intruso morto. É arrolado pelo autor, dessa forma, toda uma argumentação que, de certo modo, sintetiza a sua própria concepção de uma região que, se é algoz para uns, é acolhedora para outros.

A representação literária da Amazônia estampada nos contos de Alberto Rangel não pode ser desvinculada da sua trajetória como um autor em busca de legitimação no âmbito de um campo intelectual ainda malformado nesse início do século XX. Os vínculos por ele estabelecidos com os setores dirigentes da região amazônica, e que se mostraram necessários para um investimento literário inicial, manifestam-se diretamente no modo como a Amazônia é configurada na totalidade da obra, mas expressam a situação constrangedora do próprio autor. A ambiguidade que emerge no último conto ao se ressaltar as imagens de inferno e de paraíso para caracterizar a Amazônia, por seu turno, revela essa situação em falso na qual o autor se encontrava, impelido a manobrar os seus impulsos criativos dentro de uma margem bastante estreita. 


\section{The amazonian sertão: the hell of Alberto Rangel}

\section{Abstract}

Based on the book debut of Alberto Rangel, Inferno Verde (Green Hell), published in 1908, this article investigates the motivations and constraints present in the author's creative process, regarding the representation of the Amazon as sertão (backlands). His adherence to the style of Euclides da Cunha, and his relationship with the state administrative apparatus when he was in the region, contributed to the idea of what seemed to be a hellish aspect of the Amazon. In his understanding of the national reality, in relation to the backlands, the author saw the Amazon as a forgotten world. For a different interpretation of the stories in the book, and the recognition of this hellish representation of the Amazon, it is necessary to take into consideration the aspects related to the aspirations and anxieties of Alberto Rangel on becoming a writer and to be recognized as such.

Keywords: Amazon. Literature. Region.

\section{Referências}

BITTENCOURT, Agnello, A intelectualidade do Amazonas no limiar do século. Revista da Academia Amazonense de Letras. Manaus, n.9, outubro/1959, p. 63-80.

BOURDIEU, Pierre. A identidade e a representação; elementos para uma reflexão crítica sobre a idéia de região. In: O poder simbólico. Tradução de Fernando Tomaz. Lisboa/Rio de Janeiro: Editora Bertrand/Difel, 1989. p. 107-32.

. As regras da arte: gênese e estrutura do campo literário. Tradução de Maria Lúcia Machado. São Paulo: Companhia das Letras, 1996.

GALVÃO, Walnice Nogueira; GALOTTI, Oswaldo (orgs.). Correspondência de Euclides da Cunha. São Paulo: Edusp, 1997.

GONDIM, Neide. A invenção da Amazônia. São Paulo: Marco Zero, 1994.

LEITE, Ligia Chiappini Moraes. Velha praga? Regionalismo literário brasileiro. In: PIZARRO, Ana (org.). América Latina, palavra, literatura e cultura. São Paulo: Memorial da América Latina/Unicamp, v. 2, 1994. 
LIMA, Nísia Trindade. Um sertão chamado Brasil: intelectuais e representação geográfica da identidade nacional. Rio de Janeiro: Revan/IUPERJ/Universidade Candido Mendes, 1999.

MENEZES, Raimundo. Dicionário literário brasileiro. 2ª ed. Rio de Janeiro: Livros Técnicos e Científicos, 1978.

MICELI, Sérgio. Intelectuais à brasileira. São Paulo: Companhia das Letras, 2001.

MORAES, Péricles. Os intérpretes da Amazônia. Manaus: Valer/Governo do Estado do Amazonas, 2001.

MORAES, Raimundo. Na planície amazônica. 7ạ ed. Belo Horizonte/São Paulo: Itatiaia/Edusp, 1987.

RANGEL, Alberto. O imaginário. In: Vários autores. O conto do norte. Rio de Janeiro: Civilização Brasileira, s/d. p. 107-20.

. Euclydes da Cunha: um pouco do coração e do caráter. Rio de Janeiro: Biblioteca Nacional/Tipografia do Jornal do Comércio, agosto/1913.

. Os sertões brasileiros. Conferências nacionalistas da Biblioteca Nacional $\overline{\text { em } 17}$ de junho de 1913. Anais da Biblioteca Nacional. Rio de Janeiro: Oficina Gráfica da Biblioteca Nacional, 1916.

- Carta de Alberto Rangel para Péricles Moraes. Revista da Academia Amazonense de Letras. Manaus, no 6, 1956, p. 181-4.

. Inferno verde: cenas e cenários do Amazonas. 5 ed. Manaus: Valer/Governo do Estado do Amazonas, 2001.

SOUZA, Márcio. Mad Maria. Rio de Janeiro: Civilização Brasileira, 1980.

SÜSSEKIND, Flora. O Brasil não é longe daqui: o narrador, a viagem. São Paulo: Companhia das Letras, 1990.

WILLIAMS, Raymond. Cultura e sociedade (1780-1950). Tradução de Leônidas Hegenberg, Octanny Mota e Anísio Teixeira. São Paulo: Companhia Editora Nacional, 1969.

. O campo e a cidade: na história e na literatura. Tradução de Paulo Henriques Britto. São Paulo: Companhia das Letras, 2000.

Recebido: 22/12/2008

Aceite final: 16/03/2009 